\title{
In Vitro and In Vivo Tests of the Cidal Effects of Certain Agents for Hydatid Protoscolices
}

\author{
Dhilal Mahdi Al-Muathen \\ Department of Basic Science, College of Dentistry, Al-Mustansiriya University, Baghdad-Iraq. \\ E-mail: dhilal.almuathen4@gmail.com.
}

\begin{abstract}
Cysts from the liver of hydatidosis infected sheep were obtained from a local abattoir, live protoscolices were prepared by using of Kreb's Ringer solution plus Hydatid Cyst Fluid (4:1) and exposed to selected protoscolicidal agents (Mebendazole 5\%, Cetrimide $0.15 \%$, and Formaline 2\%) in vitro, survival times of protoscolices in the presence of chemicals was used as a criterion of protoscolicidal agents activity by using eosin stain. After treatment it was concluded that all the treated protoscolices of the study were completely killed with Mebendazole 5\% and Cetrimide $0.15 \%$ at 5 minutes of exposure, while Formaline $2 \%$ did not cause complete killing even at 15 min of exposure. furthermore the results of in vivo part of this study showed that all the treated scolices in vitro part were completely killed and did not cause hydatidosis up to 90 days post infection in laboratory albino mice.
\end{abstract}

Keywords: Echinococcus granulosus, mebendazole, cetrimide, formaline, hydatid disease, In Vitro and In Vivo study.

\section{Introduction}

Echinococcus granulosus causes cystic echinococcosis. It uses carnivores, particularly dogs and other canines, as definitive hosts. Many mammals may serve as intermediate hosts, but herbivorous species are most likely to become infected by eating eggs on contaminated herbage [1]. Man probably obtains the infection by contamination from faeces of infected dogs [2]. Cases have been reported in which liver, lungs, and brain simultaneously bore hydatids [3] and cysts may occur in almost any organ [4]. The efficacy of systemic chemotherapy is limited [5] surgery is the recommended treatment for liver hydatid cyst [6]. During the surgery and before evacuation of the cyst, protoscolicidal agents are used to be injected into the cyst in order to prevent secondary cyst formation [7]. Recurrent disease can be a major clinical problem [8] and subsequent operations are associated with a progressive increase in mortality [9]. Scolicidal agent is defined as being potent in low concentrations, acting in a short period time, being stable in cyst fluid, not affected by dilution with the cyst fluid, being able to kill the scolex in the cyst, being non-toxic, having low viscosity, and being readily available and easily prepared, as well as being inexpensive. Sergery is accompanied by chemotherapy, and in inoperable cases, chemotherapy is the only option, albendazole and mebendazole are currently used [5].

The aim of this study is to investigate in vitro and in vivo the efficacy of some chemical agents against the protoscolices of the cestode parasite E. granulosus .

\section{Materials and Methods}

Protoscolices of E. granulosus were collected aseptically from sheep liver and prepared in vitro by using of Kreb's Ringer solution plus Hydatid Cyst Fluid (4:1) as described by [10 and 11].

After standardization by using of a micropippete, since there were 2000 protoscolices/ milliliter of (K.R.S. + H.C.F., $4: 1)$.

The experimental protoscolicidal agents were dissolved in appropriate solvents to yield the required concentrations of the active protoscolicidal agents per milliliter. Mebendazole was dissolved in $1.5 \%$ formic acid, and cetrimide in 5\% ethyl alcohol and then diluted in distal water to obtaine $5 \%$ and $0.15 \%$ respectively. While formaline was diluted in distal water to obtaine $2 \%$ concentration.

The protoscolicidal property of various agents within different exposure times were 
determined, small amount of standardized protoscolices solution was mixed equally with each concentration of the protoscolicidal agent that used in this study and subjected to different exposure times, then shaked for few seconds by vortex shaker. Survival times of protoscolices in the presence of chemicals was used as a criterion of protoscolicidal agents activity [7], ten microliter of the mixed solution was aspirated and the same amount of eosin stain was added and then examined microscopically, the viability ratio were calculated by taking the number of viable protoscolices to the total number in microscopical field at low power, dead protoscolices absorbed eosin and colored red but alive protoscolices remained colorless[10].

In vivo part of the study was performed by using male albino mice of the Mus musculus Bulb-C strain, weighing 20-25g, of 5-7weeks age. Mice were divided into 5 groups, each one consisted of 3 mice. All members of each group were placed in separate cage. The first group represented positive control injected intraperitoneally with $1 \mathrm{ml}$ of a suspension that contained approximately 2000 viable protoscolices of E. granulosus. The second group was negative control injected intraperitoneally with $1 \mathrm{ml}$ of preservative medium characterized by absence of scolices. While the other groups injected with $1 \mathrm{ml}$ of protoscolices treated with different concentrations of scolicidal agents within different exposure times.

\section{Results}

Protoscolices suspended in K.R.S. + H.C.F., 4:1were treated in vitro with the protoscolicidal agents (mebendazole 5\%, cetrimide $0.15 \%$, and formaline $2 \%$ ). In this study mebendazole $5 \%$ and cetrimide $0.15 \%$ were eligible protoscolicidal agents that caused complete killing to the protoscolices at 5 minutes Tables (1 and 2).
Table (1)

Percentages of viability of the protoscolices treated with 5\%mebendazole at different exposure times.

\begin{tabular}{|c||c||c||c||}
\hline $\begin{array}{c}\text { Exposure } \\
\text { time } \\
\text { (min.) }\end{array}$ & $\begin{array}{c}\text { Total number } \\
\text { of the } \\
\text { protoscolices }\end{array}$ & $\begin{array}{c}\text { Viable number } \\
\text { of the } \\
\text { protoscolices }\end{array}$ & Viability \% \\
\hline \hline 0 & 17 & 15 & 88.2 \\
\hline \hline 1 & 20 & 16 & 80.0 \\
\hline \hline 2 & 16 & 7 & 43.8 \\
\hline \hline 3 & 20 & 6 & 30.0 \\
\hline \hline 4 & 18 & 3 & 16.7 \\
\hline \hline 5 & 15 & 0 & 0.0 \\
\hline
\end{tabular}

Table (2)

Percentages of viability of the protoscolices treated with $0.15 \%$ Cetrimide at different exposure times.

\begin{tabular}{|c||c||c||c|}
\hline $\begin{array}{c}\text { Exposure } \\
\text { time } \\
\text { (min.) }\end{array}$ & $\begin{array}{c}\text { Total number } \\
\text { of the } \\
\text { protoscolices }\end{array}$ & $\begin{array}{c}\text { Viable number } \\
\text { of the } \\
\text { protoscolices }\end{array}$ & viability \% \\
\hline \hline 0 & 15 & 14 & 93.3 \\
\hline \hline 1 & 10 & 9 & 90.0 \\
\hline \hline 2 & 20 & 14 & 70.0 \\
\hline \hline 3 & 17 & 9 & 52.9 \\
\hline \hline 4 & 18 & 6 & 33.3 \\
\hline \hline 5 & 16 & 0 & 0 \\
\hline
\end{tabular}

While Table (3) showed that formaline 2\% acted as protoscolicidal agent on the viability of the protoscolices after 16 minutes.

Table (3)

Percentages of viability of the protoscolices treated with $2 \%$ Formaline at different exposure times .

\begin{tabular}{|c||c||c||c|}
\hline $\begin{array}{c}\text { Exposure } \\
\text { time } \\
\text { (min.) }\end{array}$ & $\begin{array}{c}\text { Total number } \\
\text { of the } \\
\text { protoscolices }\end{array}$ & $\begin{array}{c}\text { Viable number } \\
\text { of the } \\
\text { protoscolices }\end{array}$ & viability \% \\
\hline \hline 0 & 20 & 18 & 90.0 \\
\hline 5 & 15 & 13 & 86.7 \\
\hline \hline 10 & 13 & 7 & 53.8 \\
\hline \hline 11 & 14 & 5 & 35.7 \\
\hline \hline 12 & 10 & 2 & 20.0 \\
\hline \hline 13 & 18 & 3 & 16.0 \\
\hline \hline 14 & 19 & 2 & 10.5 \\
\hline \hline 15 & 23 & 2 & 8.7 \\
\hline \hline 16 & 13 & 0 & 0.0 \\
\hline
\end{tabular}

In vivo results, after secondary hydatidosis in positive control was observed three months post infection, the test mice were autopised and examined visually to detect the formation of cysts and their location. Results showed that all inoculated test mice did not produce secondary hydatid cyst and they giving $100 \%$ of scolicidal activity. 


\section{Discussion}

Cyst of E. granulosus can often be removed surgically but accidentally spillage of viable protoscolices into body cavities may cause an anaphylactic reaction [12]. Instillation of a scolicidal agent into the hydatid cyst to reduce the risk of spillage of viable protoscolices is an integral part of the surgical technique for many surgeous [13]. If any drug is to be effective it must penetrate the cyst and kill its contained protoscolices and brood capsules, as well as the germinal membrane [14].

In the present study, in vitro treatment of protoscolices with 5\% mebendazole and $0.15 \%$ cetrimide showed good results, Erzurmulu and Co - workers [15] reported similar results by using mebendazole and they confirmed their results by histopathological study revealing no living germinal membrane. Frayha et al. [16] demonstrated that all incubations at 10, 5, and 1 minutes exposure times with the four concentrations of cetrimide $(1,0.5,0.1$, and $0.05 \%)$ showed that all the protoscolices were found to be completely dead, as examined by motility and staining techniques. In (2006) Hosseini et al. [17] revealed that a $100 \%$ protoscolicidal effect was observed with $0.5 \%$ cetrimide after $1 \mathrm{~min}$. of exposure.

The results of $2 \%$ formaline disagree with those observed by $\mathrm{Al}$ - Hureibi et al. [18], while agree with Houry and associates [19] who found that $2 \%$ of formaline was a potent protoscolicidal agent at $15 \mathrm{~min}$.

The living germinal membrane may still be present even if all performed viability test prove negative for the presence of protoscolices, it is important to test for it's viability by injection into animals [10]. Male albino mice were inoculated intraperitoneally with the scolices of E. granulosus. Frayha et al. [20] demonstrated that male hosts were more susceptible to infection with hydatidosis than females and observed that female mice harboured fewer and smaller cysts than males. The in vivo present results shows that all inoculated test mice with treated protoscolices did not produce secondary hydatid cyst. The absence of secondary hydatidosis does not mean the germinal membrane is all dead, but the parts of this membrane may have not been sufficient enough to produce secondary hydatidosis.

\section{References}

[1] Schmidt Gerald D., Roberts Larry S., "Foundation of Parasitology", $8^{\text {th }}$ ed., The Mc Graw. Hill companies, London, 2009.

[2] D'Alessandro A., Rausch R.L., Cuello C., Aristizabal N., "Echinococcus vogeli in men, with a review of polycystic hydatid disease in Colombia and neighbouring countries", Am. J. Trop. Med. Hyg., 28, 303 - 317, 1979.

[3] Yang Y. R., T. Sun J. Z. Zhang, Mc Manus D. P., "Molecular confirmation of a case of multiorgan cystic echinococcosis", J. Parasitol., 92, 206 - 208, 2006.

[4] Moro P. L., Gonzalez A. E., Gilman R. H., "Cystic hydatid disease", $8^{\text {th }}$ ed., W.B. Saunders Co., Philadelphia, 2000.

[5] Ramos G., Orduna A., Garcia-Yuste M., "Hydatid cyst of the lung: diagnosis and treatment", World / Surg., 25, 46-57, 2001.

[6] Yorganci K., Sayek I., "Surgical treatment of hydatid cyst of the liver in the erea of percutaneous treatment", Am. J. Surg., 184, 63-69, 2002.

[7] Saidi F., "Surgery of hydatid disease", $1^{\text {st }}$ ed., W.B. Saunders Co., London, 1976.

[8] Mathis A., Wild P., Boellger E., Kapel M. Deplazzes., "Mitochondrial ribosom as the target for the microlide antibioticin Echinococcus multilocularis", Antimicrob. Agents and Chemother., 49, 3251-3255, 2005.

[9]Amir-Jahed A.K., Pardin R., Farzad A., Bakshanden K., "Clinical echinococcosis", Annals of surgery, 182, 541-546, 1975.

[10] Smyth J. D., Barrett N. J., "Procedures for testing the viability of human hydatid cysts following surgical removal, especially after chemotherapy", Trans. Roy. Soc. Trop. Med. Hyg., 74, 649-652, 1980.

[11] Schwabe C.W., Hadidian L., Koussa M., "Host parasite relationships in echinococcosis", Am. J. Trop. Med. Hyg., 12, 338-343, 1963.

[12] Greenwood D., "Helminths", 15 $5^{\text {th }}$ ed., Churchill Livingstone, London, 1997. 
[13] Adas G., Arikan S., Kemik O., Oner A., Sahip N., Karatepe O., "Use of albendazole sulfoxide, albendazole sulfone, and combined solutions as scolicidal agents on hydatid cysts (In Vitro study)", World J. Gastroenterol.,15(1), 112-116, 2009.

[14] Chinnery J.B., Morris D. L., "Effect of albendazole sulphoxide on viability of hydatid protoscolices In Vitro", Roy. Soc. Trop. Med. Hyg., 80, 815-817, 1986.

[15] Erzurumlu K., Ozdemir M., Minmali M., Cevikbas U., "The effect of intraoperative mebendazole-albendazole applications on the hepatobiliary system", Eur. Sur. Res., 27, 340- 345, 1995.

[16] Frayha G. J., Bikhazi K. J., Kachachi T. A., "Treatment of hydatid cysts (Echinococcus granulosus) by cetrimide", Trans. Roy. Soc. Trop. Med. Hyg., 75, 447 $-450,1981$.

[17] Hosseini S. V., Ghanbarzadeh K., Barzin Z., Sadjjadi S. M., Tanideh N., Mehrabani D., "In Vitro protoscolicidal effects of hypertonic glucose on protoscolices of hydatid cyst", Korean J. Parasitol., 44(3), 239-242, 2006.

[18] Al-Hureibi A. A., Aert A., Al-Hureibi M. A., Sharawes Z., "Hepatic hydatid cysts: presentation and surgical management in Yemen", J. R. Coll. Surg. Edinb., 37, 229231, 1992.

[19] Houry S., Languille O., Huguier M., Benhamou J. P., Belghiti J., Msika S., "Sclerosing cholangitis induce by formaldehyde solution injected into the biliary tree of rats", Arch. Surg., 125, 10591061, 1990.

[20] Frayha G. J., Lawlor W. K., Dajani R. M., "Echinococcus granulosus in albino mice: effect of host sex and sex Hormones on the growth of hydatid cysts", Exp. Parasitol., 29, 225-262, 1971.
الخلاصة

جمعت الرؤيسات الأولية للأكياس العدرية من الخراف

Echinococcus المصابين بطفيلي المشوكة الحبييية granulosus بأستخدام وسط محلول كريبس رينكر + سائل الكيس العدري (1:4) لغرض معاملتها بمواد قاتلة للرؤيسات الأولية هي (الميبيندازول 5\%، السترمايد 0,15\%، الفورمالين 2\%). و قد أستخدم وقت البقاء للرؤيسات الأولية بوجود المواد الكيميائية المستخدمة كوسيلة لمعرفة فعالية هذه المواد بأستخدام صبغة الأيوسين. و قد أستتنج في هذه الدراسة أن كل من المييندازول 5\% و السسترمايد 0,15\% هو مادة قاتلة جيدة للرؤيسات الأولية خلال فنرة تعرض 5 دقائق،

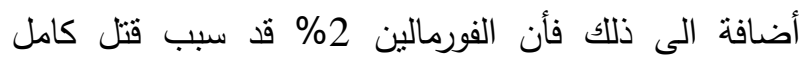
للرؤيسات الأولية في 16 دقيقة. كما و أظهرت الدراسة داخل

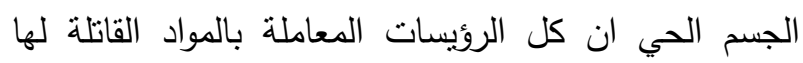
المستعملة في الجزء المختبري قد قتلت بصورة كاملة و لم انم تسبب أحداث أصابة بالأكياس المائية حتى بعد تسعين يوم من أحداث الأصابة في الفئران المختبرية. 